\title{
KKN-PPM Pengembangan Usaha Ternak Unggas Non Ayam pada Kelompok Tani di Desa Baumata Timur
}

\author{
Gemini Ermiani Mercurina Malelak, Gusti Ayu Yudiwati Lestari, Maria Rosdiana Deno Ratu, \\ I Gusti Ngurah Jelantik
}

Fakultas Peternakan, Universitas Nusa Cendana

JL. Adisucipto - Penfui, Kupang, NTT, Indonesia

Email: geminimalelak@staf.undana.ac.id

\section{ARTICLE INFO:}

Received: 2019-10-20

Revised: 2019-12-17

Accepted: 2020-02-27

Keywords:

Breeders; Innovation; Monitoring and evaluation; Raising ducks; Training and assistance

\begin{abstract}
The purpose of the KKN-PPM program is to increase the knowledge of the breeders about a proper duck raising system. The method of implementation in the field includes counseling, training and assistance, and program monitoring and evaluation. The evaluation phase is carried out on the performance of students by measuring the effective working hours of students (JKEM) which include the main activities, individual and social, and measuring the level of technology adoption by farmers using questionnaires and interviews. Interviews were conducted with 45 members of farmer groups, interviewed with questionnaire guidelines. The results of the KKN-PPM activities are that each participant has spent an effective amount of student work totaling 169 hours consisting of main activities 86 hours ( \pm 50 percent), for individual activities of 52 hours ( \pm 30 percent) and social activities of 31 hours ( \pm 20 percent). The highest adoption rate of breeders was in the types of livestock raising activities 95.56 percent and livestock health $88.89 \%$ while for fermentation, hatching and egg processing activities the adoption rates were 62.22 percent, 66.67 percent and 77.77 percent. The level of adoption of farmers for the technology provided is influenced by factors in the agricultural system they live in, there are other social activities that affect the availability of time to carry out their farming activities and whether there are additional costs if they use the technology.
\end{abstract}

() 2020 Published by University of Merdeka Malang. This is an open access article distributed under the CC BY-SA 4.0 license (https://creativecommons.org/licenses/by-sa/4.0/)

How to cite: Malelak, G. E. M., Lestari, G. A. Y., \& Ratu, M. R. D., \& Jelantik, I. G. N. (2020). KKN-PPM Pengembangan Usaha Ternak Unggas Non Ayam pada Kelompok Tani di Desa Baumata Timur. Abdimas: Jurnal Pengabdian Masyarakat Universitas Merdeka Malang, 5(1), 85-92. https://doi.org/10.26905/abdimas.v5i1.3589

\section{PENDAHULUAN}

Desa Baumata Timur terdiri dari 5 dusun dengan jumlah kepala keluarga sebanyak 543. Penduduk Desa Baumata Timur lebih dari $70 \%$ mempunyai mata pencaharian berternak/ bertani. Di Desa Baumata Timur ini terdapat 3 kelompok tani yaitu Kelompok Wanita Karia dan Kelompok Wanita Lelobaun yang terdapat di Dusun 5, dan Kelompok Maju Bersama yang berada di Dusun 3. Jenis ternak yang lasim

$\square$ Corresponding Author:

Gemini Ermiani Mercurina Malelak:

Tel. +62380881084

E-mail: geminimalelak@staf.undana.ac.id 
ABDIMAS: Jurnal Pengabdian Masyarakat Universitas Merdeka Malang

Volume 5, No 1, Maret 2020: 85-92

dipelihara adalah ternak sapi, babi, dan ayam kampung. Namun beberapa tahun belakangan ini beberapa peternak mencoba mengembangkan ternak bebek/itik, namun populasinya kurang berkembang.

Kurang berkembangnya ternak bebek di Desa Baumata Timur ini disebabkan kurang pengetahuan tentang beternak bebek (Putra, Efendi, \& Brata, 2018), peternak beranggapan bahwa memelihara ternak bebek membutuhkan banyak air dan pakan khusus. Ternak bebek yang dipelihara secara tradisional, dilepaskan berkeliaran sehingga banyak telur atau setelah menetas dimakan predator (anjing dan kucing). Disamping itu ternak bebek/itik dapat merusak tanaman disekitarnya dan mengotori lingkungan. Padahal dengan sistem pemeliharaan yang intensif dimana ternak dikandangkan, maka kebutuhan air dan pakan, pada saat bertelur dan menetas dapat diatur dan tidak mengotori ataupun merusak lingkungan.

Di daerah Baumata Timur terdapat banyak hasil limbah pertanian yang dapat diolah menjadi pakan bebek melalui fermentasi (Pudyartono \& Arisandi, 2018). Melalui kegiatan KKNPPM ini peternak diajarkan tentang bagaimana memelihara ternak bebek secara intensif/ dikandangkan dan cara pengolahan pakan fermentasi dengan memanfaatkan berbagai jenis tanaman yang terdapat dilingkungan mereka.

Ternak bebek/itik lebih efisien mengubah pakan menjadi daging. Di samping itu bebek memiliki daya adaptasi yang cukup baik, lebih tahan terhadap penyakit (Akhadiarto, 2002) Penambahan herbal: kunyit, jahe dan daun salam dalam ransum bebek dapat meningkatkan berat karkas (Sulistyoningsih, Rakhmawati, \& Mukhtar 2016).

Selain bebek, peternak juga diberikan bantuan ternak itik Jawa. Itik Jawa adalah itik penghasil telur, sehingga telurnya dapat dikonsumsi untuk memenuhi kebutuhan protein keluarga maupun dapat diolah menjadi telur asin, dapat dijual sehingga dapat membantu keadaan ekonomi keluarga (Nisa, Saraswati, \& Yuniwarti, 2017). Kemampuan bertelur itik lebih banyak dibanding ayam kampung. Walaupun kemampuan mengeram itik Jawa lebih rendah dibanding bebek/itik, namun telur itik Jawa juga dapat ditetaskan oleh itik (Wulandari, Sunarno, Saraswati, 2015). Dengan demikian kekurangan yang dimiliki oleh itik dapat teratasi dengan memelihara itik manila secara bersama-sama.

Tujuan dari kegiatan KKN-PPM bagi mahasiswa adalah untuk melaksanakan kegiatan KKN sesuai kalender akademik di Perguruan Tinggi dengan belajar dan bekerja dalam kegiatan pengembangan ternak bebek/itik dengan Jumlah jam kerja efektif (JKEM) minimal 160 jam. Tujuan kegiatan KKN-PPM bagi peternak adalah untuk meningkatkan pengetahuan masyarakat peternak tentang sistem pemeliharaan ternak bebek/itik yang benar dan mengukur tingkat inovasi masyarakat terhadap beberapa teknologi yang diberikan selama kegiatan KKN-PPM ini.
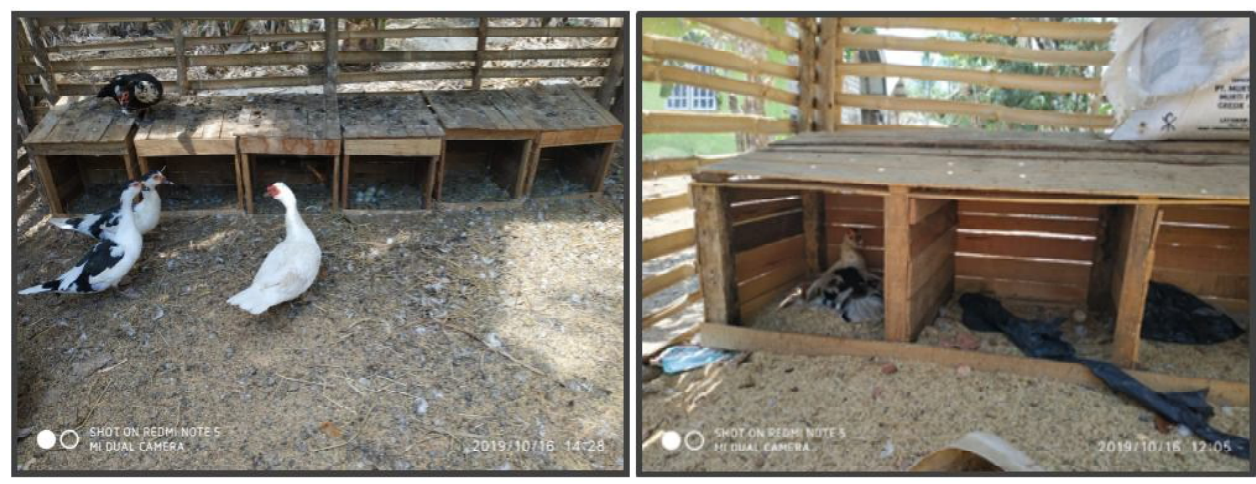

Gambar 1. Peternakan Bebek dan Itik 


\section{METODE}

Kegiatan pelaksanaan KKN-PPM ini meliputi 2 tahap yaitu: persiapan / pembekalan mahasiswa KKN-PPM di Kampus, dan pelaksanaan kegiatan KKN-PPM di desa. Persiapan dan pembekalan dilakukan dengan dua kegiatan, yaitu mekanisme dan pelaksanaan kegiatan KKN - PPM. Mekanisme kegiatan terdiri dari beberapa kegiatan yang saling mendukung, dijelaskan sebagai berikut.

\section{Menentukan sasaran}

Sasaran adalah anggota kelompok tani dari 3 kelompok tani yaitu kelompok tani Mafneken di Dusun 2. Kelompok tani Maju Bersama di Dusun 3 dan Kelompok Tani Wanita Karya di Dusun 5 tiap akelompok tani terdiri dari 10 anggota

\section{Rekrutmen peserta program KKN-PPM}

Mahasiswa yang direkrut adalah mahasiswa UNDANA asal Fakultas Peternakan (FAPET) seabanyak 23 mahasiswa, Fakultas Kedokteran Hewan (FKH) sebanyak 2 orang dan Fakultas Pertanian sebanyak 2 orang. Syarat mahasiswa yang mendaftar adalah: SKSnya telah cukup untuk memprogran KKN, dibuktikan dengan surat keterangan dari dosen wali dan prodi, untuk mendaftar. Syarat berikutnya adalah tidak sedang memprogram mata kuliah pada semester tersebut agar tidak mengganggu aktivitasnya selama kegiatan KKN PPM berjalan. Setelah pendaftaran akan dilakukan kegiatan pembekalan.

\section{Materi pembekalan dan pembagian kelompok}

Materi-materi yang diberikan pada kegiatan KKN-PPM meliputi: manajemen penyakit ternak (bagaimana mencegah dan mengobati penyakit) baik menggunakan obat-obatan maupun langkah pencegahan non medis lainnya, berdasarkan kearifan lokal yang ada. Materi berikutnya mencakup manajemen perkandangan yaitu kandang yang sesuai untuk tipe ternak dan sesuai status fisiologisnya.

Materi lainnya meliputi: pengolahan pakan fermentasi dan manajemen pemberian pakan, penetaan telur, pengolahan telur dan daging bebek yang akan membahas keutungan dan kekurangan penggunaan ternak maupun mesin tetas untuk menetaskan telur. Materi manajemen pemberian pakan membahas tentang fungsi sampai takaran pemberian pakan pada ternak unggas serta kemungkinan jenis-jenis pakan lokal yang dapat diandal sebagai pakan ternak unggas.

Manajemen pengolahan daging dan telur lebih menekankan pada cara pengolahan hasil ternak baik daging maupun telur yang dapat dijadikan kuliner rumah tangga maupun jenis kuliner yang dapat dikomersialkan, untuk memberi nilai tambah pada ternak unggas di daerah Baumata Timur.

Kegiatan pembekalan bagi mahasiswa diberikan selama 5 hari kerja. Setelah kegiatan pembekalan, mahasiswa dibagi kedalam beberapa kelompok yang bertanggung jawab untuk memberi penyuluhan pada masyarakat. Pembagian kelompok sesuai dengan minat mereka terhadap materi yang disampaikan pada saat pembekalan dan ini terkait dengan kegiatan kelompok maupun kegiatan individu mahasiswa selama kegiatan KKN-PPM. Setiap kelompok terdiri dari 2-3 orang. Mahasiswa akan membuat hand out untuk kegiatan penyuluhan di lapangan nantinya. Hand out akan dikoreksi oleh dosen pengusul sebelum dibawakan pada saat kegiatan KKN-PPM. 
ABDIMAS: Jurnal Pengabdian Masyarakat Universitas Merdeka Malang

Volume 5, No 1, Maret 2020: 85-92

Sebelum pelaksanaan KKN-PPM dilaksanakan di Desa Baumata Timur, telah dipersiapkan Jadwal pelaksanaan yang memuat (nama kegiatan dan waktu pelaksanaan). Volume total kerja yang meliputi: nama pekerjaan, nama program, volume kerja/ jumlah jam yang diperlukan untuk menyelesaikan pekerjaan tersebut dan siapa pelaksananya. Jumlah jam kerja yang diperlukan dihitung dengan cara mengalikan jumlah mahasiswa yang bekerja dikalikan dengan jumlah jam kerja yang dihabiskan dalam melakukan pekerjaan tersebut.

Kegiatan pelaksanaan ini dilakukan dalam kegiatan pelaksanaan ini melalui kegiatan penyuluhan, pelatihan dan pedampingan.

\section{Penyuluhan dan pelatihan}

Tujuan penyuluhan adalah memberi informasi kepada masyarakat tentang kebaikan atau keuntungan yang akan diraih jika mereka meningkatkan produktivitas ternak unggas mereka. Materi penyuluhan meliputi: manajemen pemeliharaan ternak bebek/itik, manajemen penetasan telur dan pengolahan pakan fermentasi. Materi lainnya adalah pengolahan daging ayam/bebek/itik dan telur.

Pelatihan dan penyuluhan dilakukan secara bersamaan tujuan dari kegiatan pelatihan ini adalah untuk meningkatkan pemahaman mereka tentang langkah-langkah yang harus mereka tempuh untuk mendapatkan hasil yang maksimal. Peningkatan pengetahuan diukur dengan metode wawancara yang berpatokan pada kuisioner yang telah disiapkan.

Materi manajemen kesehatan ternak diberikan tidak hanya untuk ternak bebek/itik namun juga untuk jenis ternak lainnya sesuai permintaan mitra, sehingga untuk kesehatan ternak sapi, kambing dan babi dimasukkan sebagai kegiatan individu.

Pelatihan manajemen pemeliharaan ternak dan penetasan telur akan dilakukan di lokasi di mana kandang akan dibangun sehingga dapat langsung ditentukan letak kandang yang akan dibangun dan desain kandang serta ukuran.

Materi manajemen penetasan telur akan diberikan pada segmen ini, dan akan dicobakan sebanyak 100 butir telur ayam kampong ditetaskan menggunakan mesin tetas. Kegiatan ini dimaksudkan umtuk memberi pemahaman yang jelas tentang faktor-faktor yang mempengaruhi telur dapat menetas atau tidak. Telur sebanyak 100 butir dan biaya listrik akan dialokasikan dari dana kegiatan KKN PPM. Materi lainnya adalah pengolahan daging dan telur juga dilakukan. Semua bahan dibebankan pada dana operasional kegiatan KKN-PPM ini.

Selain kegiatan utama KKN-PPM mahasiswa juga diwajibkan untuk melakukan kegiatan individu dan kegiatan sosial yang disesuaikan dengan kebutuhan mitra.

\section{Kegiatan Pendampingan}

Materi mengenai penetasan telur dilakukan menggunakan mesin tetas dan peserta diberi tugas untuk membalik-balik telur sesuai petunjuk yang ada sampai telur menetas. Kegiatan ini dikoordinir oleh mahasiswa KKN PPM dan dipantau oleh tim pengusul yang bertindak sebagai pembimbing lapangan. Penetasan telur menggunakan itik dilakukan pada saat pendampingan, setelah diberi bantuan itik kepada masyarakat dan ada itik yang sedang mengeram. 
Kegiatan pendampingan oleh mahasiswa dilakukan setiap hari sampai kegiatan KKNPPM berakhir. Setelah KKNPPM berakhir kegiatan pendampingan dilakukan oleh tim pengusul/ dosen pembimbing lapangan dan petugas lapangan yang ditugaskan untuk memonitor sampai itik bisa mengerami telur ayam kampong dan hanya dibatasi selama 2 periode penetasan telur saja. Selanjutnya masyarakat diharapkan dapat melakukan secara mandiri.

Pada saat pendampingan dapat juga dilakukan pengolahan telur asin atau pengasapan ayam/ itik. Permasalahan dalam bidang produksi dan manajemen dapat didiskusikan pada saat pendampingan ini.

\section{Evaluasi pelaksanaan program}

Evaluasi dilakukan 2 tahap. Tahap I dilakuan terhadap kinerja mahasiswa selama kegiatan KKNPPM dengan mengukur jam kerja efektif mahasiswa (JKEM) Tahap II dilakukan terhadap teknologi apa saja yang diterapkan oleh peternak sesuai materi penyuluhan dan pelatihan yang diberikan. Untuk mengukur adanya peningkatan pengetahuan dan ketrampilan anggota kelompok tani terhadap pengembangan usaha ternak bebek/ itik setelah kegiatan KKNPPM ini menggunakan kuisioner dan wawancara selama kegiatan KKNPPM dan 2 bulan setelah kegiatan KKNPPM ini berakhir dengan observasi yang dilakukan pada saat kegiatan pendampingan.

Semua anggota kelompok tani, sebanyak 45 orang, diwawancara dengan panduan kuisioner pada saat kegiatan membuat kandang, membuat pakan dan pada saat membuat mesin tetas dan pada saat pelaksanaan kegiatan individu maupun kegiatan sosial. Cara ini ditempuh untuk mengurangi kesan bahwa petani di wawancarai untuk mendapat data sehingga kejujuran dalam memberi informasi lebih terjamin. Jawaban diberi skoring 5 untuk yang paling diharapkan dan 1 untuk yang paling tidak diharapkan.

\section{HASIL DAN PEMBAHASAN}

\section{Jumlah kerja efektif mahasiswa}

Hasil kerja mahasiswa diukur berdasarkan jumlah kerja efektif mahasiswaa (JKEM) seperti terlihat pada Tabel 1. Untuk kegiatan utama jumlah jam kerja yang dihabiskan sebanyak 2.317 jam untuk 27 mahasiswa sehingga rata-rata setiap mahasiswa menggunakan 86 jam sedangkan untuk kegiatan individu sebanyak 52 jam dan kegiatan sosial sebanyak 31 jam.

Tabel 1. Jumlah jam kerja sesuai program yang dilakukan per orang

\begin{tabular}{|c|c|c|c|c|}
\hline No & Nama kegiatan & Program & Volume kerja & JKEM \\
\hline A & \multicolumn{4}{|c|}{ KEGIATAN UTAMA } \\
\hline \multirow[t]{6}{*}{1} & Manajemen & Pembuatan kandang bebek & 8 hari $\times 6$ jam $\times 27$ orang & 1.296 jam \\
\hline & pemeliharaan ternak & Pembuatan kotak bertelur & 3 hari $\times 2$ jam $\times 6$ orang & 36 jam \\
\hline & bebek dan itik. & Pembuatan kolam & 4 hari $\times 4$ jam $\times 15$ orang & 240 jam \\
\hline & & $\begin{array}{l}\text { Pembuatan kandang ayam } \\
\text { induk }\end{array}$ & 4 hari $\times 4$ jam $\times 3$ orang & 48 jam \\
\hline & & $\begin{array}{l}\text { Pembuatan kandang anak } \\
\text { ayam }\end{array}$ & 3 hari $\times 2$ jam $\times 6$ orang & 36 jam \\
\hline & & Sterilisasi kandang & 1 hari $\times 2$ jam $\times 3$ orang & 6jam \\
\hline \multirow[t]{2}{*}{2.} & Manajemen kesehatan & Vaksinasi & 3 hari $x 1$ jam $\times$ 3orang & 9jam \\
\hline & ternak, itik dan itik & Pengobatan penyakit & 3 hari $\times 1$ jam $\times 3$ orang & 9 jam \\
\hline
\end{tabular}


ABDIMAS: Jurnal Pengabdian Masyarakat Universitas Merdeka Malang Volume 5, No 1, Maret 2020: 85-92

\begin{tabular}{|c|c|c|c|c|}
\hline \multirow[t]{2}{*}{3} & \multirow{2}{*}{$\begin{array}{l}\text { Manajemen pakan } \\
\text { bebek/itik }\end{array}$} & Pengolahan pakan Fermentasi & 28 hari $\times 5$ jam $\times 2$ orang & 280 jam \\
\hline & & $\begin{array}{l}\text { Waktu pemberian pakan dan } \\
\text { air minum }\end{array}$ & 50 hari $\times 1$ jam $\times 6$ orang & 300 jam \\
\hline \multirow[t]{2}{*}{4.} & \multirow{2}{*}{$\begin{array}{l}\text { Manajemen penetasan } \\
\text { telur.(mesin dan } \\
\text { alamiah) }\end{array}$} & Pembuatan mesin tetas & 4 jam $\times 2$ hari $\times 6$ orang & 48 jam \\
\hline & & $\begin{array}{l}\text { Penyuluhan cara memilih } \\
\text { telur }\end{array}$ & 1 jam $\times 1$ hari $\times$ 3orang & 3 jam \\
\hline \multirow[t]{2}{*}{5} & \multirow{2}{*}{$\begin{array}{l}\text { Pengolahan daging } \\
\text { ayam/itik/bebek dan } \\
\text { telur. }\end{array}$} & $\begin{array}{l}\text { Pengolahan telur asin dan } \\
\text { pudding }\end{array}$ & 1 jam $\times 1$ hari $\times 3$ orang & 3 jam \\
\hline & & Pengolahan bebek betutu & 1 jam $\times 1$ hari $\times 3$ orang & 3 jam \\
\hline \multicolumn{5}{|c|}{ Total jam kerja kegiatan utama $\mathbf{2 . 3 1 7}$ jam } \\
\hline $\mathrm{B}$ & \multicolumn{4}{|c|}{ KEGIATAN INDIVIDU } \\
\hline \multirow[t]{2}{*}{1} & $\begin{array}{l}\text { Pemanfaatan lahan } \\
\text { pekarangan }\end{array}$ & $\begin{array}{l}\text { Menanam tanaman } \\
\text { holtikultural di polibeg }\end{array}$ & 3 hari $\times 5$ jam $\times 6$ orang & 90 jam \\
\hline & & $\begin{array}{l}\text { Pembuatan rak untuk } \\
\text { tanaman }\end{array}$ & 2 hari $\times 5$ jamx 6 orang & 60 jam \\
\hline \multirow[t]{2}{*}{2} & Menanam tanaman & Membuat bedeng & 2 hari $\times 4$ jam $\times 9$ orang & 72 jam \\
\hline & $\begin{array}{l}\text { holtikultural di lahan } \\
\text { tidur }\end{array}$ & Menanan sayuran & & 72 jam \\
\hline 3 & $\begin{array}{l}\text { Menanam jagung di } \\
\text { sawah }\end{array}$ & Menanam jagung di sawah & 1hari $\times 10$ jam $\times 9$ orang & 90 jam \\
\hline \multirow[t]{2}{*}{4} & Pengolahan marungga & Membuat stik marungga & 1 hari $\times 4$ jam $\times 3$ orang & 12 jam \\
\hline & & Membuat pudding & 1 hari $\times 3$ jam $\times 3$ orang & 9 jam \\
\hline 5. & Membuat kotak sampah & Membuat kotak sampah & 2 hari $\times 4$ jam $\times 3$ orang & 24 jam \\
\hline \multirow[t]{2}{*}{6.} & Vaksinasi dan & Ternak sapi & 3 hari $\times 4$ jam $\times 6$ orang & 72 jam \\
\hline & pemberian vitamin & Ternak babi & & \\
\hline 7. & $\begin{array}{l}\text { Membuat obat cacing } \\
\text { dan antibiotik alami }\end{array}$ & Untuk ternak ayam dan itik & 2 hari $\times 4$ jam $\times 9$ orang & 72 jam \\
\hline \multirow[t]{2}{*}{8.} & Pengolahan pangan & Keripik pisang & 1 hari $\times 4$ jam $\times 3$ orang & 12 jam \\
\hline & & Marning jagung & 2 hari $\times 4$ jam $\times 2$ orang & 16 jam \\
\hline 9 & $\begin{array}{l}\text { Pembuatan kotak } \\
\text { bertelur itik }\end{array}$ & Membuat 5 kotak & 2 hari $\times 4$ jam $\times 6$ orang & 48 jam \\
\hline 10 & Pengolahan limbah & Pembuatan bokasi orang & 7 hari $\times 4$ jam $\times 27$ orang & 756 jam \\
\hline \multicolumn{4}{|c|}{ Jumlah JKEM B } & 1.405 jam \\
\hline \multicolumn{5}{|c|}{ KEGIATAN SOSIAL } \\
\hline 1 & Upacara bendera & $\begin{array}{l}\text { Upacara hari Pendidikan } \\
\text { Nasional }\end{array}$ & 1 jam $\times 1$ hari $\times 27$ orang & 27 jam \\
\hline \multirow[t]{9}{*}{2} & Baktti sosial & $\begin{array}{l}\text { Perbaikan jalan masuk kantor } \\
\text { desa }\end{array}$ & 2 jam $\times 4$ hari $\times 27$ orang & 216jam \\
\hline & & $\begin{array}{l}\text { Pembersihan lingkungan } \\
\text { kantor camat }\end{array}$ & 2 jam $\times 1$ hari $\times 18$ orang & 36 jam \\
\hline & & Pembersihan mata air & 2 jam $\times 1$ hari $\times 27$ orang & 56 jam \\
\hline & & $\begin{array}{l}\text { Pembuatan fondasi rumah } \\
\text { masyarakat }\end{array}$ & 4 jam $\times 6$ hari $\times 9$ orang & 216 jam \\
\hline & & $\begin{array}{l}\text { Membuka jalan baru ke } \\
\text { pemukiman }\end{array}$ & 4 jam $\times 4$ hari $\times 9$ orang & 144 jam \\
\hline & & Membuat pagar PAUD & 4 jam $\times 3$ harix 9 orang & 108 jam \\
\hline & $\begin{array}{l}\text { Menghadiri acara } \\
\text { peminangan, } \\
\text { pernikahan, } \\
\text { penguburan, kebaktian } \\
\text { di gereja. }\end{array}$ & 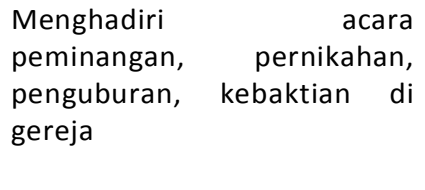 & 1 hari $\times 1$ jam $\times 27$ orang & 27 jam \\
\hline & Mengajar anak SD & & 1 hari $\times 2$ jam $\times 9$ orang & 18 jam \\
\hline & & Total JKEM C. & & 848 jam \\
\hline \multicolumn{4}{|c|}{ Total volume kegiatan selama KKN PPM( $A+B+C)$} & 4.570 jam \\
\hline \multicolumn{5}{|c|}{ Rata-rata JKEM per orang selama KKNPPM 169,259 jam } \\
\hline \multicolumn{5}{|c|}{ Keterangan: JKEM $=\mathrm{n} \times \mathrm{y} . \mathrm{n}=\sum$ mahasiswa. $\mathrm{y}=$ rata - rata JKEM } \\
\hline
\end{tabular}


Jam kerja efektif mahasiswa adalah sebanyak 169 jam. Dengan beban kegiatan utama sebanyak \pm $50 \%$, dengan kegiatan individu sebanyak $\pm 30 \%$ dan kegiatan sosial $\pm 20 \%$, sesuai dengan ketentuan kegiatan KKN.

\section{Tingkat adopsi peternak terhadap jenis kegiatan yang diberikan selama kegiatan KKN- PPM}

Dari data yang terkumpul melalui wawancara dengan menggunakan kuisioner maka didapat tingkat adopsi peternak seperti terlihat pada Tabel 2. Terlihat bahwa tingkat adopsi paling tinggi adalah pada jenis kegiatan kesehatan ternak sebanyak 88,89\% pemeliharaan ternak sebanyak 95,56\% sedangkan untuk kegiatan pakan fermentasi, penetasan telur dan pengolahan telur tingkat adopsinya paling rendah berturutturut $62,22 \%, 66,67 \%$ dan $77,77 \%$.

Tabel 3. Tingkat adopsi peternak terhadap jenis kegiatan yang diberikan selama kegiatan KKNPPM

\begin{tabular}{lccc}
\hline \multicolumn{1}{c}{ Jenis Kegiatan } & \multicolumn{3}{c}{ Tingkat Adopsi (\%) } \\
\cline { 2 - 4 } & Rendah & Sedang & Tinggi \\
\hline Kesehatan ternak & 0,02 & 0,09 & 88,89 \\
Manajemen pemeliharaan ternak & 0,00 & 4,44 & 95,56 \\
Pakan fermentasi & 62,22 & 33,33 & 4,44 \\
Penetasan telur & 66,67 & 0,18 & 0,04 \\
Pengolahan daging & 33,33 & 44,44 & 22,22 \\
Pengolahan telur & 77,77 & 11,11 & 11,11 \\
\hline
\end{tabular}

Tingginya tingkat adopsi terhadap sistem pemeliharaan ternak dimana ternak dikandangkan berhubungan dengan sistem pertanian yang dijalani oleh masyarakat setempat karena jika tidak dikandangkan tanami akan beresiko terhadap tanaman yang mereka. Sumberdaya alam menjadi faktor utama untuk melakukan usaha ternak bebek/itik. Peternak harus menyediakan pakan, wilayah produksi tanaman pangan, dan proses pengembangan ternak bebek/itik (Dewi, 2019). Demikian juga dengan kesehatan ternak dimana pengalaman peternak bahwa pada musim- musm tertentu tingkat kematian ternak sangat tinggi dan mengakibatkan kerugian yang sangat tinggi.

Rendahnya tingkat adopsi terhadap pengolahan pakan fermentasi disebabkan karena kurangnya ketersediaan waktu untuk mengolah sehubungan dengan adanya berbagai kegiatan sosial seperti pernikahan dan kematian dan bertepatan dengan waktu pembersihan lahan kebun untuk musin tanam pada saat hujan sehingga ketersediuaan waktu untuk mengolah sangat terbatas. Sedangkan rendahnya tingkat adopsi untuk kegiatan penetasan dan pengolahan telur disebabkan karena produksi telur yang belum terlalu banyak dan masih untuk dikonsumsi. Di samping itu penggunaan mesin tetas harus menggunakan listrik, sehingga menambah biaya pengeluaran, sedangkan dari ternak tersebut belum bisa menambah penghasilan mereka.

\section{SIMPULAN DAN SARAN}

Mahasiswa telah melaksanakan kegiatan KKNPPM dengan jumlah kerja efektif mahasiswa (JKEM) 169 jam telah memenuhi ketentusn KKNPPM dimana batas minimal JKEM adalah 160 jam. 
ABDIMAS: Jurnal Pengabdian Masyarakat Universitas Merdeka Malang

Volume 5, No 1, Maret 2020: 85-92

Tingkat adopsi peternak terhadap teknologi yang diberikan di pengaruhi olah faktor sistem pertanian yang mereka jalani, adanya kegiatan social lainnya yang mempengaruhi ketersediaan waktu untuk melaksanakan kegiatan beternak mereka dan ada tidaknya penambahan biaya jika mereka menggunakan teknologi tersebut.

\section{DAFTAR PUSTAKA}

Akhadiarto, S. (2002). Kualitas Fisik Daging Itik pada Berbagai Umur Pemotongan. Pusat Pengkajian dan Penerapan Teknologi Budidaya Pertanian. BPPT, Bogor

Dewi, R. K. (2019). Analisis potensi wilayah pengembangan ternak Ruminansia di Kabupaten Lamongan. Jurnal Ternak, 9(2), 5-11. https://doi.org/10.30736/ternak.v9i2.31

Nisa, R. K., Saraswati, T. R. \& Yuniwarti, E. Y. W. (2017). Kadar kolesterol dan vitamin A pada telur Itik Pengging, Itik Tegal, dan Itik Magelang. Buletin Anatomi dan Fisiologi, 2(2), 114-119. https://doi.org/10.14710/baf.2.2.2017.114-119

Pudyartono \& Arisandi, M. L. (2018). Pemberdayaan masyarakat dengan pembuatan pakan ternak jerami fermentasi di Desa Pucakwangi Kecamatan Babat Kabupaten Lamongan. Jurnal Ternak, 9(2), 1-4. https://doi.org/10.30736/ternak.v9i2.29

Putra, P. D., Efendi, H., \& Brata, W. W. W. (2018). Peningkatan pendapatan peternak bebek melalui pelatihan pakan ternak dan kewirausahaan. Jurnal Pengabdian dan Pemberdayaan Masyarakat, 2(1), 57-63. https://doi.org/10.30595/jppm.v2i1.1713

Sulistyoningsih, M., Rakhmawati, R., \& Mukhtar, A. (2016). Peningkatan kualitas bobot badan dan karkas dengan tambahan herbal pada bebek pedaging. Seminar Nasional Hasil Penelitian 2016 Lembaga Penelitian dan Pengabdian Kepada Masyarakat Universitas PGRI. Prosiding Seminar Nasional, 68-72. Semarang.

Wulandari, D., Sunarno, Saraswati, T. R. (2015). Perbedaan somatometri Itik Tegal, Itik Magelang, dan Itik Pengging. Bioma: Berkala IImiah Biologi, 17(2), 94-101.

https://doi.org/10.14710/bioma.17.2.94-101 